\title{
PENGARUH STRUKTUR KEPEMILIKAN TERHADAP KINERJA PERUSAHAAN PADA SEKTOR KEUANGAN YANG TERCATAT DI BURSA EFEK INDONESIA PADA TAHUN 2007-2010
}

\author{
Rini Tri Hastuti dan Rousilita Suhendah \\ Fakultas Ekonomi Universitas Tarumanagara \\ email:apampam@yahoo.com dan :rousita12@gmail.com)
}

\begin{abstract}
This research examine the effect of insider ownership and institutional ownership on corporate performance on financial sector that listed in Indonesia Stock Exchange on 2007-2010.There is $11^{\text {th }}$ banking on this sample with multiple purposive sampling criteria. Research data was collected from Indonesian Capital Market Diectory. This research findings are insider ownership significant effected operational expenses to operational income ratio and Loan to deposit ratio. But this failed to examine that institusional ownership effect operational expenses to operational income ratio and Loan to deposit ratio. The result of this study revealed that insider ownership and institusional ownership did not affect leverage.
\end{abstract}

Key words: Kepemilikan manajerial, kepemilikan institusional , leverage.

\begin{abstract}
Abstrak: Penelitian ini menguji pengaruh kepemilikan insider dan kepemilikan institusional terhadap kinerja perusahaan pada sektor keuangan yang terdaftar di Bursa Efek Indonesia pada 2007-2010.There adalah 11 perbankan pada sampel ini dengan kriteria beberapa purposive sampling. Data penelitian dikumpulkan dari Capital Indonesia Pasar Diectory. Temuan penelitian ini adalah kepemilikan insider signifikan biaya operasional yang terpengaruh terhadap pendapatan operasional dan Loan to deposit ratio. Tapi ini gagal untuk memeriksa bahwa biaya operasional berpengaruh kepemilikan institusional terhadap pendapatan operasional dan Loan to deposit ratio. Hasil penelitian ini menunjukkan bahwa kepemilikan insider dan kepemilikan institusional tidak mempengaruhi leverage.
\end{abstract}

Kata kunci: manajerial Kepemilikan, institusional kepemilikan, leverage.

\section{PENDAHULUAN}

Perusahaan go public membutuhkan pengelolaan corporate governance yang baik. Mkanisme corporate governance dapat dijalankan dengan tindakan pengawasan melalui keterlibatan pemegang saham mayoritas dalam tindakan manajemen. Mekanisme pengawasan tersebut diterapkan dengan cara peningkatan persentase kepemilikan saham perusahaan untuk manajemen, proporsi komisaris independen terhadap dewan komisaris, dan keberadaan komite audit. Ketiga hal ini menjadi indikator penerapan corporate governance dalam suatu perusahaan (Leni dan Rosmita, 2010).

Menurut Jensen dan Meckling (1976), kepemilikan manajerial dan kepemilikan institusional adalah dua proksi corporate governance utama yang membantu mengendalikan masalah keagenan. Kepemilikan Manajerial merupakan kepemilikan saham oleh manajemen perusahaan yang diukur dengan persentase jumlah saham yang 
dimiliki oleh manajemen, sedangkan kepemilikan institusional merupakan kepemilikan saham oleh pemerintah, institusi keuangan, institusi berbadan hukum, institusi luar negeri, dana perwalian serta institusi lainnya pada akhir tahun.

Corporate governance merupakan serangkaian mekanisme yang dapat melindungi pihak-pihak minoritas dari ekspropriasi yang dilakukan oleh para manajer dan pemegang saham pengendali dengan penekanan pada mekanisme legal (Shleiver dan Vishny, 1997). Pengaturan dan pengimplemetasian Good Corporate Governance memerlukan komitmen dari seluruh jajaran organisasi dan dimulai dengan penetapan kebijakan dasar serta tata tertib yang harus dianut oleh top manajemen dan penerapan kode etik yang harus dipatuhi oleh semua pihak yang ada di dalamnya (Etty, 2009). Terdapat lima prinsip utama yang terkandung dalam Good Corporate Governance (Achmad Daniri dalam Etty, 2009) yaitu; keterbukaan (transparency), akuntabilitas (accountability), pertanggungjawaban (responsibility), kewajaran (fairness), dan independensi (independency).

Bukti empiris yang diperoleh dari hasil riset Zhuang pada tahun 2000 menunjukkan masih lemahnya perusahaan-perusahaan publik di Indonesia dalam mengelola perusahaan dibanding negara-negara Asia Tenggara, hal ini ditunjukkan oleh masih lemahnya standarstandar akuntansi dan regulasi, pertanggungjawaban terhadap para pemegang saham, standar-standar pengungkapan dan transparansi serta proses-proses kepengurusan perusahaan. Hal ini secara tidak langsung menunjukkan masih lemahnya perusahaanperusahaan publik di Indonesia dalam menjalankan manajemen yang baik dalam memuaskan stakeholder perusahaan.

Penelitian yang dilakukan oleh Ashbaugh, et al. (2006) terhadap 1500 perusahaan di Amerika Serikat, menunjukkan bahwa perusahaan-perusahaan yang melaksanakan good corporate governance mengalami peningkatan peringkat kredit (firm credit rating) yang signifikan. Penelitian yang dilakukan oleh Alexakis et al. (2006) terhadap perusahaanperusahaan yang listing di pasar modal Yunani menunjukkan bahwa perusahaanperusahaan yang melaksakan corporate governance secara baik mengalami peningkatan rata-rata return saham dan mengalami penurunan risiko yang signifikan. Penelitian yang di-lakukan Drobetz, et al. (2003) terhadap perusahaan-perusahaan yang listing di pasar modal Jerman menunjukkan bahwa perusahaan-perusahaan yang melaksanakan good corporate governance mengalami peningkatan expected stock return yang signifikan.

Penelitian yang dilakukan oleh Firth et al. (2002) terhadap perusahaan-perusahaan yang listing di pasar modal Hongkong menunjukkan bahwa, perusahaan-perusahaan yang melaksanakan good corporate governance mengalami peningkatan kinerja perusahaan (corporate performance) yang signifikan. Demikian pula dengan penelitian yang dilakukan oleh Brown dan Caylor (2004) di Georgia menunjukkan bahwa perusahaanperusahaan yang melaksanakan good corporate governance mengalami peningkatan kinerja perusahaan (corporate performance) yang signifikan. Penelitian yang dilakukan oleh Cornett et al (2006) terhadap perusahaan-perusahaan yang tergabung dalam S\&P 100, juga menunjukkan hasil yang sama dimana perusahaan-perusahaan yang melaksanakan good corporate governance mengalami peningkatan kinerja perusahaan yang signifikan.

Masalah dalam perusahaan sering timbul karena manajer tidak semata-mata bertindak untuk memaksimalkan kekayaan pemegang saham, melainkan mereka cenderung mencari cara untuk melindungi kepentingan mereka sendiri yang biasa disebut dengan masalah keagenan (agency problem). Untuk mengatasi masalah tersebut maka digunakan corporate governance dengan proksi struktur kepemilikan oleh pihak dalam 
maupun luar perusahaan. Struktur kepemilikan dipercaya memiliki kemampuan untuk mempengaruhi jalannya perusahaan yang nantinya dapat mempengaruhi kinerja perusahaan dan mengatasi agency problem tersebut.

Dengan adanya konsentrasi kepemilikan, maka pemegang saham besar seperti kepemilikan institusional dapat memonitor tim manajemen secara lebih efektif sehingga dapat meningkatkan kinerja perusahaan. Tingginya kepemilikan institusi diharapkan dapat meningkatkan pengawasan terhadap perusahaan. Situasi tersebut akan berbeda bila manajer juga berperan sebagai pemegang saham (kepemilikan manajerial). Dalam perusahaan dengan kepemilikan manajerial, manajer yang berperan sekaligus sebagai pemegang saham, akan menselaraskan kepentingannya dengan kepentingannya sebagai pemegang saham. Sementara dalam perusahaan tanpa kepemilikan manajerial, manajer yang bukan pemegang saham kemungkinan hanya mementingkan kepentingannya sendiri.

Pada dasarnya bank tidak berbeda dengan perusahaan komoditas atau perusahaan jasa lainnya. Dalam hal ini bank menghasilkan output berupa kredit dari input berupa dana simpanan masyarakat, sehingga bank dapat menjembatani kepentingan pihak pemilik dana dengan pihak yang membutuhkan dana atau disebut menjalankan fungsi intermediasi. Industri perbankan mempunyai peranan yang amat penting terhadap pembangunan ekonomi. Sejarah perekonomian Indonesia menunjukkan bahwa ekonomi bangsa ini bergerak seiring dengan industri perbankan.

\section{KAJAIN TEORI}

Teori Keagenan (Agency Theory). Jensen dan Meckling (1976) mengusulkan suatu teori terhadap perusahaan (Agency Theory) didasarkan pada konflik kepentingan antara berbagai pihak yang terlibat dalam kontrak - pemegang saham, manajer perusahaan dan pemegang hutang. Menurut Jensen dan Meckling (1976) kontrak antara manajer sebagai agent dengan principal menyebabkan terjadinya pemisahan tugas yang mengakibatkan terjadinya perbedaan kepentingan. Pemisahan kepemilikan dan pengendalian menyebabkan manajer bertindak tidak sesuai dengan keinginan principal. Dalam melakukan tugas manajerial, manajer memiliki tujuan pribadi yang berbeda dengan tujuan principal dalam memaksimalkan kemakmuran pemegang saham. Pemisahan kepemilikan dan pengendalian perusahaan disebut konflik keagenan (agency conflict).

Dalam konsep agency theory, setiap pihak mempunyai motivasi berbeda sesuai dengan kepentingan masing-masing dan apabila pihak-pihak tersebut berusaha untuk memaksimalkan atau mempertahankan tingkat kemakmuran yang dikehendaki masingmasing pihak, maka timbul konflik kepentingan antara manajer sebagai agent dengan pemilik perusahaan sebagai pihak principal. Agent berusaha untuk memaksimumkan penerimaan fee kontraktual, dan principal berusaha memperoleh return atas penggunaan sumber daya. Konflik tersebut makin memuncak karena pihak principal tidak dapat memonitor atau melakukan pengawasan aktivitas sehari-hari yang dilakukan agent untuk memastikan bahwa agent bekerja sesuai dengan keinginan principal.

Stakeholder Theory. Stakeholder theory mengatakan bahwa perusahaan bukanlah entitas yang hanya beroperasi untuk kepentingannya sendiri namun harus memberikan manfaat bagi stakeholdernya (pemegang saham, kreditor, konsumen, supplier, pemerintah, masyarakat, analis dan pihak lain). Dengan demikian, keberadaan suatu perusahaan sangat dipengaruhi oleh dukungan yang diberikan oleh stakeholder kepada perusahaan tersebut. 
Gray, Kouhy dan Adams (1994, p. 53) dalam Chairiri (2008) mengatakan bahwa kelangsungan hidup perusahaan tergantung pada dukungan stakeholder dan dukungan tersebut harus dicari sehingga aktivitas perusahaan adalah untuk mencari dukungan tersebut. Makin powerful stakeholder, makin besar usaha perusahaan untuk beradaptasi. Pengungkapan sosial dianggap sebagai bagian dari dialog antara perusahaan dengan stakeholdernya.

Corporate Governance. Dalam arti luas Corporate governance menjelaskan tata kelola perusahaan yang mengatur perusahaan sendiri, khususnya peran dewan. Cara kerja corporate governance perusahaan melalui semua sistem dan prosedur yang beroperasi dalam sebuah organisasi untuk memastikan perusahaan sudah melakukan pengelolaan dengan benar. Dalam arti lain, corporate governance adalah hubungan antara semua pemangku kepentingan dalam perusahaan termasuk pemegang saham, direksi, dan manajemen perusahaan, berdasarkan hak perusahaan (corporate charter), peraturan, kebijakan formal dan aturan hukum.

Struktur Kepemilikan. Struktur kepemilikan merupakan jenis institusi atau perusahaan yang memegang saham terbesar dalam suatu perusahaan (Wahyudi dan Pawestri, 2006). Struktur kepemilikan dapat berupa investor individual, pemerintah, dan institusi swasta. Struktur kepemilikan terbagi dalam beberapa kategori. Secara spesifik kategori struktur kepemilikan meliputi kepemilikan oleh institusi domestik, institusi asing, pemerintah, karyawan dan individual domestik. Struktur kepemilikan akan memiliki motivasi yang berbeda dalam memonitor perusahaan serta manajemen dan dewan direksinya.

Struktur kepemilikan dipercaya memiliki kemampuan untuk mempengaruhi jalannya perusahaan yang nantinya dapat mempengaruhi kinerja perusahaan. Agency problem dapat dikurangi dengan adanya struktur kepemilikan. Struktur kepemilikan merupakan suatu mekanisme untuk mengurangi konflik antara manajemen dan pemegang saham (Faisal, 2005). Jensen dan Meckling (1976) dalam Faisal (2005) menyatakan bahwa kepemilikan manajerial dan kepemilikan institusional adalah dua mekanisme corporate governance yang dapat mengendalikan masalah keagenan.

Kinerja Perusahaan. Kinerja perusahaan merupakan penentuan ukuran-ukuran tertentu yang dapat mengukur keberhasilan suatu perusahaan dalam menghasilkan laba (Sucipto, 2003). Kinerja perusahaan merupakan hal penting yang harus dicapai oleh setiap perusahaan dimana pun, karena kinerja merupakan cerminan dari kemampuan perusahaan dalam mengelola dan mengalokasikan sumber dayanya. Kinerja perusahaan adalah kemampuan perusahaan dalam menjelaskan operasionalnya (Payatma, 2001 dalam Sabrina, 2010).

Biaya Operasional Terhadap Pendapatan Operasional. Biaya Operasional terhadap Pendapatan Operasional (BOPO) merupakan rasio efisiensi yang digunakan untuk mengukur kemampuan manajemen bank dalam mengendalikan biaya operasional yang dikeluarkan bank untuk memperkecil kemungkinan suatu bank dalam kondisi bermasalah.

Leverage, Loan to Deposit Ratio. Leverage sering disebut juga rasio kebijakan hutang. Kreditur lebih menyukai rasio hutang yang rendah karena semakin rendah rasio ini, maka semakin besar perlindungan terhadap kerugian kreditur dalam peristiwa likuidasi. Di sisi 
lain, pemegang saham akan menginginkan leverage yang lebih besar karena akan dapat meningkatkan laba yang diharapkan.

Dalam penelitian ini, rasio likuiditas yang digunakan adalah Loan to Deposit Ratio (LDR). $L D R$ adalah rasio keuangan perusahaan perbankan yang berhubungan dengan aspek likuiditas. $L D R$ adalah suatu pengukuran tradisional yang menunjukkan deposito berjangka, giro, tabungan, dan lain-lain yang digunakan dalam memenuhi permohonan pinjaman (loan requests) nasabahnya.

Pertumbuhan Dana Pihak Ketiga. Dana masyarakat adalah dana-dana yang berasal dari masyarakat, baik perorangan maupun badan usaha, yang diperoleh bank dengan menggunakan berbagai instrumen produk simpanan yang dimiliki oleh bank. Dana-dana pihak ketiga yang dihimpun dari masyarakat (Dana Pihak Ketiga) merupakan sumber dana terbesar yang paling diandalkan oleh bank (mencapai 80\%-90\% dari seluruh dana yang dikelola oleh bank) (Dendawijaya, 2003 dalam Chilla dan Hermana, 2010).

Total Asset, Capital Adequacy Ratio, Return On Asset. Manfaat ekonomi masa depan yang terwujud dalam aktiva adalah potensi dari aktiva tersebut untuk memberikan sumbangan, baik langsung maupun tidak langsung, arus kas dan setara kas kepada perusahaan. Manullang (2002) menyatakan bahwa rasio permodalan yang lazim digunakan untuk mengukur kesehatan bank adalah Capital Adequacy Ratio (CAR). Besarnya $C A R$ diukur dari rasio antara modal sendiri terhadap Aktiva Tertimbang Menurut Risiko (ATMR).

Return On Asset (ROA) adalah salah satu bentuk dari rasio profitabilitas yang dimaksudkan untuk mengukur kemampuan perusahaan atas keseluruhan dana yang ditanamkan dalam aktivitas yang digunakan untuk aktivitas operasi perusahaan dengan tujuan menghasilkan laba dengan memanfaatkan aktiva yang dimilikinya.

Hipotesis. Penelitian ini mengembangkan enam hipotesis, yaitu:

1. Hala : Struktur kepemilikan manajerial berpengaruh terhadap biaya operasional terhadap pendapatan operasional (BOPO) dengan pertumbuhan dana pihak ketiga (GROWTHDPK), total asset, Capital Adequacy Ratio (CAR), dan Return on Asset (ROA) sebagai variabel kontrol.

2. Ha1b : Struktur kepemilikan institusional berpengaruh terhadap terhadap biaya operasional terhadap pendapatan operasional (BOPO) dengan pertumbuhan dana pihak ketiga (GROWTHDPK), total asset, Capital Adequacy Ratio (CAR), dan Return on Asset (ROA) sebagai variabel control

3. Ha2a : Struktur kepemilikan manajerial berpengaruh terhadap Loan to Deposit Ratio (LDR) dengan pertumbuhan dana pihak ketiga (GROWTHDPK), total asset, Capital Adequacy Ratio (CAR), dan Return on Asset (ROA) sebagai variabel control.

4. Ha2b : Struktur kepemilikan institusional berpengaruh terhadap Loan to Deposit Ratio (LDR) dengan pertumbuhan dana pihak ketiga (GROWTHDPK), total asset, Capital Adequacy Ratio (CAR), dan Return on Asset (ROA) sebagai variabel control.

5. Ha3a : Struktur kepemilikan manajerial berpengaruh terhadap leverage dengan pertumbuhan dana pihak ketiga (GROWTHDPK), total asset, Capital Adequacy Ratio (CAR), dan Return on Asset (ROA) sebagai variabel control. 
6. Ha3b : Kepemilikan institusional berpengaruh terhadap leverage dengan pertumbuhan dana pihak ketiga (GROWTHDPK), total asset, Capital Adequacy Ratio (CAR), dan Return on Asset (ROA) sebagai variabel control.

\section{METODE}

Populasi dalam penelitian ini adalah perusahaan yang terdaftar di Bursa Efek Indonesia selama tahun 2007 sampai dengan 2010. Penelitian menggunakan data sekunder berupa laporan keuangan perusahaan yang terdaftar di Indonesia Capital Market Directory (ICMD) pada tahun 2007 sampai 2010. Teknik pengumpulan sampel menggunakan purposive sampling method dengan kriteria adalah: 1). Perusahaan-perusahaan sektor keuangan yang terdaftar di BEI selama tahun 2007 sampai dengan 2010, 2).Perusahaanperusahaan tersebut harus pernah mengungkapkan persentase kepemilikan manajerial dan kepemilikan institusional secara bersama-sama dalam rentang tahun 2007 sampai dengan 2010, 3). Bank pemerintah (persero) dan bank umum swasta nasional yang sahamnya telah tercatat di Bursa Efek Indonesia, yang beroperasi di Indonesia, 4). Masih beroperasi hingga tahun 2010, 5).Saham bank telah tercatat di Bursa Efek Indonesia minimal sejak tahun 2007, 6).Tersedia daftar pemegang saham lengkap dengan proporsi kepemilikannya, 7). Tersedia laporan keuangan tahunan publikasi tahun 2007 sampai dengan tahun 2010 yang terdiri dari: Neraca, Laporan laba/rugi dan saldo laba, Laporan perubahan ekuitas, laporan kewajiban penyediaan modal minimum, laporan kualitas aktiva produktif dan informasi lainnya, dan catatan atas laporan keuangan.

Penelitian ini mengembangkan tiga variabel dependen yaitu BOPO, LDR, dan Leverage, 2 variabel independen kepemilikan manajerial dan kepemilikan institusional, serta empat variabel kontol yaitu pertumbuhan dana pihak ketiga (GROWTHDPK), total asset, Capital Adequacy Ratio (CAR), dan Return on Asset (ROA).Penjelasan perhitungan masing - masing variabel adalah sebagai berikut:

1. Variabel Dependen. Variabel dependen pertama adalah Rasio Biaya Operasional terhadap Pendapatan Operasional (BOPO) yang sering disebut rasio efisiensi diukur dengan perbandingan antara biaya operasional dengan pendapatan operasional dengan rumus :

$$
\mathrm{BOPO}=\frac{\text { Bizya operasional }}{\text { Pendapatan operasional }}
$$

Variabel dependen kedua adalah Loan to Deposit Ratio (LDR) Deposit Ratio) merupakan perbandingan antara kredit yang disalurkan perbankan terhadap penghimpunan dana pihak ketiga dengan rumus:

$$
\text { LDR }=\frac{\text { Jurlah kredit yang diberikan }}{\text { Total dana pihak ketiga }}
$$

Variabel dependen ketiga adalah Leverage yang diukur dengan membagi total hutang dengan total asset yang diformulasikan sebagai berikut: (Jensen et al, 1992).

$$
\text { Debt it }=\frac{\text { TD it }}{\text { Total aset it }}
$$


Keterangan:

TD it = Jumlah total hutang perusahaan i pada periode $\mathrm{t}$

Total Asset it $=$ Total aset yang dimiliki perusahaan $\mathrm{i}$ pada periode $\mathrm{t}$

2. Variabel independent. Variabel independen pertama kepemilikan Manajerial merupakan persentase kepemilikan saham oleh pihak manajemen yang diukur dengan rumus :

$$
\% \text { Kepemilikan Manajerial }=\frac{\text { Jumlah saham Manajemen }}{\text { Jumlah saham yang beredar }}
$$

Variabel independen kedua kepemilikan Institusional merupakan proporsi kepemilikan saham pada akhir tahun yang dimiliki oleh lembaga, seperti asuransi, bank atau institusi lain yang diukur dengan rumus :

$$
\% \text { Kepemilikan Institusional }=\frac{\text { Jumlah saham Institusional }}{\text { Jumlah saham yang beredar }}
$$

3. Variabel Kontrol

a. Pertumbuhan Dana Pihak Ketiga merupakan simpanan pihak ketiga bukan bank yang terdiri dari Giro, Tabungan, dan Simpanan Berjangka yang diukur dengan rumus:

$$
\text { GROWTHDFK }-\frac{\text { DPK tahun }(t)-\text { DPK tahun }(t-1)}{\text { DPK tainu }(t)}
$$

b. Total Asset sebagai variabel kontrol digunakan untuk menghitung perbedaan biaya dan modal yang dimiliki oleh setiap bank yang berhubungan dengan ukuran bank untuk mengukur kemampuan bank dalam melakukan diferensiasi produk yang diukur dengan rumus : log aset $=\log$ total asset bank $\mathrm{i}$

c. Capital Adequacy Ratio) sebagai variabel kontrol dihitung dengan membagi modal sendiri dengan aktiva tertimbang menurut rasio ATMR (sesuai SE No.6/23/DPNP tgl 31 Mei 2004) dengan satuan persen (\%). Rumusnya adalah:

$$
\mathrm{CAR}=\frac{\text { Modal bank }}{\text { Aktiva tertimbang menurut resiko }}
$$

d. Return of Asset diukur dengan membandingkan laba sebelum pajak dengan rata-rata total aset bank yang bersangkutan dengan rumus :

$$
\text { ROA }=\frac{\text { Laba sebelum pajak }}{\text { Rata-rata total aset }}
$$

Alat analisis yang digunakan untuk mengestimasi persamaan dalam model penelitian ini adalah alat analisis regresi berganda. Analisis regresi berganda digunakan untuk membentuk persamaan regresi yang melibatkan dua atau lebih variabel bebas. Perhitungan analisis regresi ini dilakukan dengan menggunakan program SPSS 19.0. Sebelum melakukan uji regresi, data yang terkumpul dianalisis terlebih dahulu dengan melakukan uji asumsi klasik. Uji asumsi klasik yang digunakan pada penelitian ini adalah normalitas, autokorelasi, multikolinieritas, dan heteroskedastisitas. Uji-t dilakukan untuk menguji koefisien regresi secara parsial, yaitu untuk menguji pengaruh signifikansi dari suatu variabel independen terhadap variabel dependen jika variabel independen yang lain 
dianggap konstan. Uji t dilakukan untuk menguji hipotesis 1-6 dengan tingkat signifikasi $95 \%$.

\section{HASIL DAN PEMBAHASAN}

Pada penelitian ini yang menjadi obyek penelitian adalah semua perusahaan perbankan yang go public dan terdaftar di Bursa Efek Indonesia dari tahun 2007-2010 dengan menggunakan teknik purposive random sampling diperoleh sampel berjumlah 11 perusahaan perbankan.

Dari Tabel 1 statistik deskriptif diperoleh hasil bahwa kepemilikan manajerial memiliki nilai minimum sebesar $0 \%$, nilai maksimum $17,1 \%$ dan nilai rata -rata sebesar 1,105. Nilai minimum pada kepemilikan manajerial menunjukkan bahwa pada perusahaan sampel sama sekali tidak terdapat proporsi kepemilikan manajerial, sedangkan nilai maksimum menunjukkan bahwa pada perusahaan yang menjadi obyek penelitian terdapat proporsi kepemilikan manajer sebesar 17,1 \% dari seluruh jumlah kepemilikan yang ada di perusahaan.

Kepemilikan Institusional memiliki nilai minimum sebesar 10,4\%, nilai maksimum 97,54\% dan nilai rata -rata sebesar 6,58\%. Nilai maksimum kepemilikan insitusional menunjukkan bahwa proporsi kepemilikan insitusi pada perusahaan sampel sebesar 97,54\% atau dengan kata lain pada perusahaan sampel terdapat kepemilikan lain selain manajer ( Tabel 1). Dari Tabel 1 Nilai minimum, maksimum dan rata-rata BOPO ( biaya operasional per pendapatan operasional) adalah 39,19\%, 89,07\% dan 6,69\% . Nilai minimum, maksimum dan rata-rata untuk LDR (Loan to Deposit Ratio) adalah 20,85\% , $144,7 \%$ dan $7,498 \%$. Sedangkan nilai minimum, maksimum dan nilai rata-rata untuk leverage (debt) adalah 66,24\%, 94,28\% dan 8,82\%.

Tabel 1. Statistik Deskriptif

\begin{tabular}{lrrrrr}
\hline \multicolumn{7}{c}{ Descriptive Statistics } \\
\hline INSID.OWNER & N & \multicolumn{1}{c}{ Minimum } & Maximum & \multicolumn{1}{c}{ Mean } & Std. Deviation \\
INST.OWNER & 44 & .000 & 17.100 & 1.10523 & 3.456970 \\
GROWTH.DPK & 44 & 10.400 & 97.540 & $6.58336 \mathrm{E} 1$ & 24.901864 \\
TOT.ASSET & 44 & -9.000 & 71.700 & $2.56486 \mathrm{E} 1$ & 19.437305 \\
CAR & 44 & 6.067 & 8.511 & 7.34275 & .784716 \\
ROA & 44 & 11.190 & 33.270 & $1.82032 \mathrm{E} 1$ & 5.315145 \\
BOPO & 44 & .030 & 6.200 & 2.30614 & 1.252885 \\
LDR & 44 & 39.190 & 89.070 & $6.68798 \mathrm{E} 1$ & 11.368020 \\
LEVERAGE & 44 & 20.850 & 144.700 & $7.49775 \mathrm{E} 1$ & 22.687288 \\
Valid N (listwise) & 44 & 66.240 & 94.280 & $8.81514 \mathrm{E} 1$ & 4.882134 \\
\hline
\end{tabular}

Hasil Uji Normalitas. Dari Tabel 2 pada hasil uji normalitas menggunakan uji Kolmogorov Smirnov masing masing variabel menunjukkan nilai signifikasi lebih besar dari 0.05 sehingga dapat disimpulkan nilai residual tahun 2007-2010 terdistribusi normal atau memenuhi asumsi klasik. 
Tabel 2. Uji Normalitas Model Regresi 1,2, dan 3

\begin{tabular}{ll}
\hline Variabel & Asymp. Sig. (2-tailed) \\
\hline INSD.OWNER ( Insider Ownership) & 0,652 \\
INST.OWNER ( Institutional Ownership) & 0,317 \\
GROWTHDPK( Pertumbuhan dana pihak ketiga) & 0,358 \\
TOT.ASSET ( Total Asset) & 0.429 \\
CAR( Capital Adequacy Ratio) & 0,292 \\
ROA( Return on Asset) & 0,641 \\
BOPO (Biaya Operasional terhadap Pendapatan Operasional) & 0,146 \\
LDR ( Loan to Deposit Ratio) & 0,582 \\
LEVERAGE (Kebijakan Hutang ) & 0,068 \\
\hline
\end{tabular}

Hasil Uji Multikolinearitas. Dari Tabel 3 terlihat bahwa nilai tolerance untuk masingmasing variabel lebih besar dari 0.1 dan variance inflation factor (VIF) lebih kecil dari 10. Dengan demikian dapat disimpulkan bahwa model regresi tidak terdapat gejala multikolinearitas. Hal ini berarti antara variabel bebas yang ada dalam model regresi tidak terjadi korelasi

Tabel 3. Uji Multikolinearitas Model Regresi 1, 2 dan 3

\begin{tabular}{|c|c|c|}
\hline & \multicolumn{2}{|c|}{ Collinearity Statistics } \\
\hline & Tolerance & VIF \\
\hline INSD.OWNER ( Insider Ownership) & 0,699 & 1,430 \\
\hline INST.OWNER (Institutional Ownership) & 0,633 & 1,580 \\
\hline GROWTHDPK (Pertumbuhan dana pihak ketiga) & 0,774 & 1,293 \\
\hline TOT.ASSET ( Total Asset) & 0,499 & 2,004 \\
\hline CAR ( Capital Adequacy Ratio) & 0,577 & 1,734 \\
\hline ROA( Return on Asset) & 0,863 & 1,159 \\
\hline
\end{tabular}

Hasil Uji Autokorelasi. Dari Tabel Durbin Watson dengan jumlah sampel sebanyak 44 dan 2 variabel independen diperoleh nilai du sebesar 1,612 dan 4-du sebesar 2,398. Pada Tabel 4 diperoleh hasil bahwa nilai DW pada model regresi 1 menunjukkan angka sebesar 2,213 ( berada antara 1,612 dan 2,398 ) sehingga pada model regresi 1 bebas dari autokorelasi. Model regresi 2 dan 3 juga menunjukkan angka DW sebesar 1,9 dan 1,871 sehingga model regresi 2 dan 3 juga bebas dari autokorelasi.

Tabel 4. Uji Autokorelasi Model Regresi 1, 2 dan 3

\begin{tabular}{llll}
\hline & Model Regresi 1 & Model Regresi 2 & Model Regresi 3 \\
\hline Nilai Durbin-Watson & 2,213 & 1,900 & 1.871 \\
Dependent Variabel & BOPO & LDR & LEVERAGE \\
\hline
\end{tabular}

Hasil Uji Heteroskedastisitas. Pada Tabel 5 untuk model regresi 1, 2, dan 3 nilai signifikansi untuk variabel insider Ownership, institutional ownership, pertumbuhan dana pihak ketiga, total asset, CAR( Capital Adequacy Ratio), ROA(Return On Asset) menunjukkan angka lebih besar dari 0,05 yang berarti dalam model regresi tidak terjadi heteroskedastisitas. 
Tabel 5. Uji Heteroskedastisitas Model Regresi 1, 2 dan 3

\begin{tabular}{|c|c|c|c|}
\hline & Model Regresi 1 & Model Regresi 2 & Model Regresi 3 \\
\hline & Sig & Sig & Sig \\
\hline $\begin{array}{l}\text { INSD.OWNER } \\
\text { Ownership) }\end{array}$ & 0,168 & 0,053 & 0,289 \\
\hline $\begin{array}{l}\text { INST.OWNER } \\
\text { Ownership) }\end{array}$ & 0,755 & 0,427 & 0,149 \\
\hline $\begin{array}{l}\text { GROWTHDPK (Pertumbuhan } \\
\text { dana pihak ketiga) }\end{array}$ & 0,992 & 0,457 & 0,923 \\
\hline TOT.ASSET ( Total Asset) & 0,164 & 0,077 & 0,190 \\
\hline CAR ( Capital Adequacy Ratio) & 0,718 & 0,992 & 0,769 \\
\hline ROA( Return on Asset) & 0,621 & 0,849 & 0,287 \\
\hline Dependent variabel & $B O P O$ & $L D R$ & LEVERAGE \\
\hline
\end{tabular}

Hasil Uji Regresi Berganda Model Regresi 1, 2 dan 3. Berdasarkan hasil pengujian model regresi 1 pada Tabel 6 dapat diinterpretasikan persamaan model regresi 1 untuk periode amatan adalah :

$$
\text { BOPO = 105,581 - 5,359 INSID.OWNERit + 0,065 INST.OWNERit + 0,127 }
$$

GROWTHDPK -3,537 TOT.ASSETit - 0,794 CAR - 3,611 ROA + it

Dari persamaan model regresi 1, dapat diberikan analisis yaitu nilai konstanta sebesar 105,581 menunjukkan bahwa jika variabel independen dianggap konstan, maka terjadi kenaikan BOPO (biaya operasional terhadap pendapatan operasional) sebesar 105,581. Koefisien regresi kepemilikan manajerial (INSID. OWNER) sebesar -5,359 menunjukkan bahwa setiap terjadi penambahan jumlah kepemilikan manajerial sebesar satu satuan dapat mengurangi biaya operasional terhadap pendapatan operasional sebesar 5,359 satuan. Koefisien regresi kepemilikan institusional (INST.OWNER) sebesar 0,065 menunjukkan bahwa setiap terjadi penambahan kepemilikan institusional (INST.OWNER) sebesar satu satuan menyebabkan kenaikan biaya operasional terhadap pendapatan operasional sebesar 0,065 .

Pada Tabel 6 atas hasil pengujian model regresi 2 dapat dibuat persamaan regresi 2 sebagai berikut :

$$
\begin{aligned}
& \text { LDR }=121,160-11,150 \text { INSID.OWNERit }-0,261 \text { INST.OWNERit }-0.070 \\
& \text { GROWTHDPK - 8,423 TOT.ASSETit + 0,817 CAR +6,299 ROA + it }
\end{aligned}
$$

Pada persamaan model regresi 2, dapat diberikan analisis yaitu nilai konstanta sebesar 121,160 menunjukkan bahwa jika variabel independen dianggap konstan, maka terjadi kenaikan LDR ( Loan to Deposit Ratio ) sebesar 121,160. Koefisien regresi kepemilikan manajerial (INSID. OWNER) sebesar -11,150 menunjukkan bahwa setiap terjadi penambahan jumlah kepemilikan manajerial sebesar satu satuan dapat mengurangi LDR sebesar 11,150 satuan. Koefisien regresi kepemilikan institusional (INST.OWNER) sebesar -0,261 menunjukkan bahwa setiap terjadi penambahan kepemilikan institusional (INST.OWNER) sebesar satu satuan menyebabkan penurunan LDR sebesar 0, 261.

Pada tabel 6 hasil pengujian model regresi 3 dapat dibuat persamaan regresi 3 sebagai berikut:

LEVERAGE it $=86,806+1,669$ INSID.OWNERit + 0,058 INST.OWNERit + 0,029 GROWTHDPK + 0,935 TOT.ASSETit - 0,435 CAR - 0,590 ROA + it 
Pada persamaan model regresi 3, dapat diberikan analisis yaitu nilai konstanta sebesar 86,806 menunjukkan bahwa jika variabel independen dianggap konstan, maka terjadi kenaikan DEBT (Loan to Deposit Ratio) sebesar 86,806. Koefisien regresi kepemilikan manajerial (INSID. OWNER) sebesar 1,669 menunjukkan bahwa setiap terjadi penambahan jumlah kepemilikan manajerial sebesar satu satuan dapat menambah LEVERAGE sebesar 1,669 satuan. Koefisien regresi kepemilikan institusional (INST.OWNER) sebesar 0,058 menunjukkan bahwa setiap terjadi penambahan kepemilikan institusional (INST.OWNER) sebesar satu satuan menyebabkan kenaikan DEBT sebesar 0,058.

Tabel 6. Hasil Uji Model Regresi 1, 2 dan 3

\begin{tabular}{|c|c|c|c|c|c|c|}
\hline \multirow{3}{*}{ Model } & \multicolumn{2}{|c|}{ Model Regresi 1} & \multicolumn{2}{|c|}{ Model Regresi 2} & \multicolumn{2}{|c|}{ Model Regresi 3} \\
\hline & \multicolumn{2}{|c|}{ Unstandardized } & \multicolumn{2}{|c|}{$\begin{array}{l}\text { Unstandardized } \\
\text { Coefficients }\end{array}$} & \multicolumn{2}{|c|}{$\begin{array}{l}\text { Unstandardized } \\
\text { Coefficient }\end{array}$} \\
\hline & B & Sig & B & sig & B & Sig \\
\hline (Constant) & 105,581 & 0,000 & 121,160 & 0,008 & 86,806 & 0,000 \\
\hline INSD.OWNER & $-5,359$ & $\mathbf{0 , 0 3 5}$ & $-11,150$ & 0,046 & 1,669 & 0,160 \\
\hline INST.OWNER & 0,065 & 0,356 & $-0,261$ & 0,096 & 0,058 & 0,088 \\
\hline GROWTHDPK & 0,127 & 0,122 & $-0,070$ & 0,695 & 0,029 & 0,450 \\
\hline TOT.ASSET & $-3,537$ & 0,162 & $-8,423$ & 0,132 & 0,935 & 0,432 \\
\hline$C A R$ & $-0,794$ & 0,025 & 0,817 & 0,283 & $-0,435$ & 0,011 \\
\hline$R O A$ & $-3,611$ & 0,004 & 6,299 & 0,020 & $-0,590$ & 0,300 \\
\hline Dependent variabel & $B O P O$ & & $L D R$ & & LEVEK & \\
\hline
\end{tabular}

Hasil Uji t. Dari Tabel 6 pada pengujian hipotesis INSD.OWNER (kepemilikan manajerial) terhadap BOPO (biaya operasional terhadap pendapatan nasional) memiliki nilai signifikansi sebesar 0,035 . Hal ini menunjukkan bahwa nilai signifikansi lebih kecil dari 0,05 yang berarti Ha1a diterima atau INSD.OWNER (kepemilikan manajerial) berpengaruh signifikan terhadap BOPO (biaya operasional terhadap pendapatan nasional). Hal ini menunjukkan bahwa manajer perusahaan perbankan memiliki peran yang amat penting dalam pengambilan keputusan terhadap biaya operasional perbankan. Pengaruh kepemilikan manajerial terhadap biaya operasional memiliki hubungan negatif yang berarti bila kepemilikan manajer di perusahaan makin besar, maka manajer tersebut akan melakukan tindakan yang membuat kinerja perusahaan terlihat lebih baik dengan memperkecil biaya operasional sehingga laba perusahaan makin tinggi. Hal ini sesuai dengan konsep agency teori yaitu manajer akan melakukan tindakan untuk kepentingan sendiri dalam rangka untuk mendapatkan imbal jasa berupa bonus. Penelitian ini sama dengan hasil penelitian yang dilakukan oleh Etty M (2009) dan Devi Indrayani (2009) yang menyatakan bahwa struktur kepemilikan berpengaruh terhadap BOPO dan kinerja perusahaan.

Dari Tabel 6 pada pengujian hipotesis INST.OWNER (kepemilikan institusional) terhadap BOPO (biaya operasional terhadap pendapatan nasional) memiliki nilai signifikansi sebesar 0,356. Hal ini menunjukkan bahwa nilai signifikansi lebih besar dari 0,05 yang berarti Halb ditolak atau INST. OWNER (kepemilikan institusional) tidak berpengaruh signifikan terhadap BOPO (biaya operasional terhadap pendapatan nasional). Hal ini terjadi karena semakin banyak kepemilikan institusional di dalam perbankan, mengakibatkan manajer tidak dapat berbuat untuk kepentingan sendiri dikarenakan banyak pihak yang mengawasi segala tindakan yang dilakukan oleh manajer. 
Pada pengujian hipotesis INSD.OWNER (kepemilikan manajerial) terhadap LDR (Loan to Deposit Ratio) memiliki nilai signifikansi sebesar 0,046. Hal ini menunjukkan bahwa nilai signifikansi lebih kecil dari 0,05 yang berarti $\mathrm{Ha} 2 \mathrm{a}$ diterima atau INSD.OWNER (kepemilikan manajerial) berpengaruh signifikan terhadap LDR ( Loan to Deposit Ratio). Hal ini menunjukkan bahwa dalam pengambilan kebijakan perbankan berupa pemberian kredit dan penghimpunan dana peran manajer masih sangat dibutuhkan. Bila dilihat hubungan antara INSD.OWNER (kepemilikan manajerial) terhadap LDR (Loan to Deposit Ratio) yang memiliki hubungan negatif menunjukkan bahwa kepemilikan manajerial yang makin besar di perbankan mengakibatkan pengambilan keputusan dalam memberikan kredit dan penghimpunan dana makin semakin berkurang karena makin banyak manajer maka kepentingan pribadi makin besar sehingga menimbulkan konflik kepentingan. Hasil ini sesuai dengan konsep agency theory.

Dari Tabel 6 pada pengujian hipotesis INST.OWNER (kepemilikan institusional) terhadap LDR (Loan to Deposit Ratio) memiliki nilai signifikansi sebesar 0,096. Hal ini menunjukkan bahwa nilai signifikansi lebih besar dari 0,05 yang berarti Ha2b ditolak atau INST.OWNER ( kepemilikan institusional) tidak berpengaruh signifikan terhadap LDR (Loan to Deposit Ratio). Hal ini menunjukkan bahwa dalam pengambilan kebijakan perbankan berupa pemberian kredit dan penghimpunan dana peran kepemilikan institusional tidak dibutuhkan.

Pada pengujian hipotesis INSD.OWNER (kepemilikan manajerial) terhadap DEBT memiliki nilai signifikansi sebesar 0,160 . Hal ini menunjukkan bahwa nilai signifikansi lebih besar dari 0,05 yang berarti Ha3a ditolak atau INSD.OWNER (kepemilikan manajerial) tidak berpengaruh signifikan terhadap LEVERAGE . Hal ini menunjukkan bahwa manajer perusahaan publik di Indonesia terutama manajer perbankan bukanlah sebagai faktor penentu dalam pengambilan kebijakan pendanaan ( hutang) karena jumlah saham yang dimiliki pihak manajer pada perusahaan perbankan yang go publik di Indonesia masih sangat kecil. Hasil penelitian ini sama dengan penelitian yang dilakukan oleh Devi dan Gugus (2008) yang menyatakan bahwa kepemilikan manajerial tidak berpengaruh terhadap kebijakan hutang.

Tabel 7. Hasil Penelitian Pengujian Hipotesis 1, 2 dan 3

\begin{tabular}{llll}
\hline Hipotesis & & & $\begin{array}{l}\text { Diterima / } \\
\text { Ditolak }\end{array}$ \\
\hline $\begin{array}{l}\text { Ha1a : INSD.OWNER (Kepemilikan manajerial) } \\
\text { signifikan terhadap BOPO. }\end{array}$ & berpengaruh & Diterima \\
Ha1b : INST.OWNER (Kepemilikan institusional) & berpengaruh & Ditolak \\
signifikan terhadap BOPO & & & \\
Ha2a : INSD.OWNER (Kepemilikan manajerial) & berpengaruh & Diterima \\
signifikan terhadap LDR & & \\
Ha2b : INST.OWNER (Kepemilikan institusional) & berpengaruh & Ditolak \\
signifikan terhadap LDR & & \\
$\begin{array}{l}\text { Ha3a : INSD.OWNER ( Kepemilikan manajerial) } \\
\text { signifikan terhadap LEVERAGE }\end{array}$ & berpengaruh & Ditolak \\
$\begin{array}{l}\text { Ha3b : INST.OWNER ( Kepemilikan institusional }) \\
\text { signifikan terhadap LEVERAGE }\end{array}$ & berpengaruh & Ditolak \\
\hline
\end{tabular}

Pada pengujian hipotesis INST.OWNER (kepemilikan institusional) terhadap LEVERAGE memiliki nilai signifikansi sebesar 0,088. Hal ini menunjukkan bahwa nilai 
signifikansi lebih besar dari 0,05 yang berarti Ha3b ditolak atau INST.OWNER (kepemilikan institusional ) tidak berpengaruh signifikan terhadap DEBT. Hasil penelitian ini tidak sama dengan penelitian yang dilakukan oleh Devi dan Gugus (2008) yang menjelaskan bahwa kepemilikan institusional berpengaruh terhadap kebijakan hutang.

Dari hasil pengujian hipotesis pengaruh INSD.OWNER dan INST.OWNER terhadap BOPO (Hala dan Ha1b), INSD.OWNER dan INST.OWNER terhadap LDR (Ha2a dan Ha2b), dan INSD.OWNER dan INST.OWNER terhadap LEVERAGE (Ha3a dan Ha3b), dapat diringkas dalam Tabel 7 di atas.

\section{PENUTUP}

Simpulan. Berdasarkan hasil yang diperoleh dari proses pengolahan data dengan menggunakan analisis regresi linier berganda maka dapat diambil kesimpulan sebagai berikut: (1)Kepemilikan manajerial (INSD.OWNER) berpengaruh signifikan terhadap BOPO, (2) Kepemilikan institusional (INST.OWNER) tidak berpengaruh signifikan terhadap BOPO, (3) Kepemilikan manajerial (INSD.OWNER) berpengaruh signifikan terhadap LDR, (4) Kepemilikan institusional (INST.OWNER) tidak berpengaruh signifikan terhadap LDR, (5) Kepemilikan manajerial (INSD.OWNER) tidak berpengaruh signifikan terhadap LEVERAGE, (6) Kepemilikan institusional (INST.OWNER) tidak berpengaruh signifikan terhadap LEVERAGE.

Saran. Meskipun hasil penelitian memberikan dukungan terhadap hipotesis yang diajukan, namun ada beberapa keterbatasan dalam penelitian sehingga disarankan: (1). Jumlah sampel yang digunakan pada penelitian ini hanya perusahaan perbankan sehingga pada penelitian lanjutan diharapkan menggunakan sampel pada jenis industri yang berbeda dengan jumlah sampel yang diperbanyak, (2) Periode penelitian diperpanjang dan perbaikan pada desain penelitian.

Penelitian ini diharapkan dapat memberi implikasi bagi para investor atau pemegang saham bahwa dalam pengambilan keputusan yang berkaitan dengan pemberian pinjaman dan penghimpunan dana masyarakat pada perbankan, pihak manajer masih memegang peranan yang sangat penting. Namun dalam pengambilan keputusan yang menyangkut pendanaan baik berupa pinjaman atau menerbitkan ekuitas, peran manajer tidak begitu berpengaruh.

\section{DAFTAR RUJUKAN}

Abdullah, Faisal. (2003) Dasar-Dasar Manajemen Keuangan. Malang : UMM Press.

Agnes, Sawir. (2005) Analisis Kinerja Keuangan dan Perencanaan Keuangan Perusahaan. PT Gramedia Pustaka, Jakarta.

Alexakis, C.A., (2006) An Empirical of The Visible Effect of Corporate Governance: The Case of Greece, Managerial Finance, Vol. 32, No. 8, pp. 673-684, 2006.

Ali, Masyhud. (2004) Asset Liability Management: Menyiasati Risiko Pasar dan Risiko Operasional. Jakarta: PT.Gramedia.

Ananta, Aris. (1987) Landasan Ekonometrika, Gramedia Jakarta.

Ang, Robbert, (1997) Buku Pintar Pasar Modal Indonesia. Jakarta: Mediasoft Indonesia. Anto, (2007), http://anthoex.multiply.com/ 
Ashbough, H., Collins, D., and Laford, R., (2004) Corporate Governance the Cost of Equity Capital, Working Paper, University of Lowa.

Bank Indonesia. (2004) Surat Edaran No.6/ 23/ DPNP tanggal 31 Mei 2004, Sistem Penilaian Tingkat Kesehatan Bank Umum. Jakarta. Tersedia di www.bi.go.id

Bevan, Alan A and Jo Danbolt., (2000) Dinamics in the Determinants of Capital Structure in the UK. Departement of Accounting and Finance University of Glasgow Working Paper Series.

Brigham, E. F., dan Houston, J. F., (2001) Manajemen Keuangan. Edisi Kedelapan (Terjemahan), Salemba Empat, Jakarta.

Brown, Lawrence, and J., Caylor, (2004) Corporate Governance and Firm Performance, Boston Accounting Research Colloquium 15th, Desember, 2004.

Chairiri, Anis. (2008) Kritik Sosial Atas Pemakaian Teori dalam Penelitian Pengungkapan Sosial dan Lingkungan, Jurnal Maksi, Vol.8, No.2, Agustus 2008: 151-169.

Chilla, Stiady dan Hermana, Budi, (2010) Analysis of Fundamental Factors Influence and Systematic Risk on Share Price Banking Listed in Stock Exchange Indonesia (BEI), Simposioum Economy Faculty, 2010, Gunadarma University

Cornett, Marcia, and Alan, J., (2006) Earnings Management, Corporate Governance, and True Financial Performance, ECGI Finance Working Paper, May, 2006.

Deegan, C., Rankin, M. \& Voght, P. (2000) 'Firms' disclosure reactions to major social incidents: Australian evidence', Accounting Forum, Vol. 24, Iss. 1, pp. 101-130.

Diana, Devi, N A., dan Irianto, Gugus. (2008) Pengaruh Kepemilikan Manajerial, Kepemilikan Institusional dan Sebaran Kepemilikan Terhadap Kebijakan Hutang Perusahaan Ditinjau dari Teori Keagenan, Emisi Vol.1, No.1, April 2008: 1-16

Drobetz, Wolfgang, Andreas, and Heinz, (2003) Corporate Governance and Expected Stock Returns: Evidance From Germany, ECGI Finance Working Paper, Februari, 2003.

Downes, John dan Goodman, Jordan Elliot, (1999) Kamus Istilah Keuangan \& Investasi, diterjemahkan oleh Soesanto Buhidarmo. Jakarta: Elex Media Komputindo, 1994.

Dwi, Novi dan Bambang, Riyanto, LS. (2005) Corporate Governance dan Kinerja: Analisis Pengaruh Compliance Reporting dan Struktur Dewan Terhadap Kinerja”, SNA VIII Solo, 2005

Etty, Murwaningsari. (2009) Hubungan Corporate Governance, Corporate Social Responsibilities dan Corporate Financial Performance Dalam Satu Continuum, Jurnal Akuntansi dan Keuangan, Vol.11, Bo.1, Mei 2009: 30-41.

Euis, Soleha dan Taswan. (2002) Pengaruh Kebijakan Hutang Terhadap Nilai Perusahaan Serta Beberapa Faktor Yang Mempengaruhinya, Jurnal Bisnis dan Ekonomi Vol. 9, no. 2 .

Faisal, (2005) Analisis Agency Costs, Struktur Kepemilikan dan Mekanisme Corporate Governance. Jurnal Riset Akuntansi Indonesia. Vol. 8, No. 2, Hal. 175-190.

Faizal. (2004) Analisis Agency Costs, Struktur Kepemilikan dan Mekanisme Corporate Governance, Simposium Nasional Akuntansi VII Denpasar-Bali. Hal 197-207.

Firth, M., and Rui, O., (2002) Simultaneous Relationship Among Ownerships, Corporate Governance and Financial Performa, Working Paper The Hongkong Polytechnic University.

Ghozali, Imam. (2005) Structural equation modeling: Teori, konsep, dan aplikasi dengan program Lisrel. Semarang: Badan penerbit Universitas Dipenogoro. 
. (2006) Aplikasi Analisis Multivariate dengan Program SPSS. Semarang: Badan Penerbit Universitas Diponegoro.

dan Chariri, Anis. (2007) Teori Akuntansi, Badan Penerbit Universitas Diponegoro Semarang.

Gujarati, D., (2003) Basic Econometrics, Fourth Edition, Mc Graw Hill Book Company, New York.

Halim, (2011) Kasus Pembobolan Bank di Indonesia Menyerupai Kasus Bank-Bank di Dunia, www.vibiznews.com

Hanafi, Mamduh M dan Fitri Ismiyanti. (2003) Kepemilikan Manajerial, Kepemilikan Institusional, Risiko, Kebijakan Hutang dan Kebijakan Dividen: Analisis Persamaan Simultan, Jurnal Simposium Nasional Akuntansi IV, Hal: 260-277.

Hanke, J.E., dan Reitsch, A.G. (1998) Bussiness Forecsting. (6th. ed). London: PrenticeHall International Ltd.

Hartono, Jogiyanto dan Putu, Anom, Mahadwartha. (2002) Uji Teori Keagenan dalam Hubungan Interpendensi antara Kebijakan Hutang dengan kebijakan Dividen, Jurnal Simposium Nasional Akuntansi V, Hal: 635-647.

Haruman, Tendi. (2008) Pengaruh Struktur Kepemilikan Terhadap Keputusan Keuangan dan Nilai Perusahaan. Jurnal Simposium Nasional Akuntansi XI, Pontianak.

Hastuti, Theresia D., (2005) Hubungan Antara good Corporate Governance Terhadap Struktur Kepemilikan dengan Kinerja Keuangan, SNA VIII Solo, September: 2005.

Hermeindito, Kaaro. (2001) Analisis Leverage dan Dividen Dalam Lingkungan Ketidakpastian: Pendekatan Pecking Order Theory dan Balancing Theory, Jurnal Simposium Nasional Akuntansi IV.

Horne, James Van dan John M. Wachowicz, Jr. (1998) Prinsip-Prinsip Manajemen Keuangan. Jakarta: Salemba Empat.

Indrayani, Devi. (2009) Analisis Hubungan Struktur kepemilikan dengan Kinerja Keuangan Perusahaan Perbankan Persero dan Perusahaan Perbankan umum Swasta nasional Go Public Periode 2007 - 2008, Simposium Akuntansi, Universitas Gunadarma.

Jensen, G.R; Solberg dan T.S.Zorn. (1992). Simultaneous Determinant of Insider ownership, debt and devident policies. Journal of financial and quantitative analysis. , Michael C. and William H. Meckling, (1976) Theory of the firm: Managerial behavior, agency costs, and ownership structure, Journal of Financial Economics 3, 305-360.

Jogi, Christiawan, Yulius, dan Tarigan, Josua, (2007) Kepemilikan Manajerial: Kebijakan Hutang, Kinerja dan Nilai Perusahaan, Jurnal Akuntansi dan Keuangan, Vol.9, No.1, Mei 2007: 1-8

Jogiyanto dam Tarjo. (2003) Analisa Free Cash Flow dan kepemilikan Manajerial terhadap Kebijakan Utang pada Perusahaan Publik di Indonesia, Jurnal Simposium Nasional Akuntansi IV, Hal:278-295

Kasmir. (2003) Bank Dan Lembaga Keuangan lainnya. Jakarta: PT Raja Grafindo Persada

Kieso, Donald E., Jerry J. Weygandt., and Terry D. Warfield. (2001) Intermediate Accounting, 10th Edition, John Wiley \& Sons Inc., New York, 2001.

Komite Nasional Kebijakan Governance. (2006) Pedoman Umum Gooc Corporate Governance Indonesia.

Kuncoro. (2001) Metode Kuantitatif : Teori dan Aplikasi Untuk Bisnis dan Ekonomi, UPP AMP YKPN, Yogyakarta. 
Laurence, A. Manullang. (2002) Analisis Pengaruh Rentabilitas Terhadap Rasio Kecukupan Modal Pada Bank Tabungan Pensiunan Nasional, Media Riset Bisnis dan Manajemen, Vol. 2, No.1, 2002, hal. 26-47

Latumaerissa, Julius R, (1999) Mengenal Aspek-Aspek Operasi Bank Umum, Bumi Aksara, Jakarta.

Leni dan Rasyid, Rosmita. (2010) Implikasi Penerapan Corporate Governance Terhadap Perusahaan Pada Perusahaan Bank, Jurnal Akuntansi, Tahun XIV, No.01, Januari 2010: $38-53$

M. Faisal Abdullah, (2003) Manajemen Perbankan : Teknik Analisis Kinerja Keuangan Bank, Penerbit Universitas Muhamadiyah Malang

M. Manullang. (2002) Dasar-dasar Manajemen. Yogyakarta: BPFE.

Masdupi, Erni. (2005) Analisis Dampak Struktur kepemilikan Pada kebijakan Hutang Dalam Mengontrol Konflik Keagenan, Jurnal Ekonomi dan Bisnis Indonesia, Vol.20, No.1, hal: 57-69

Moh'd, Mahmoud A., Perry, Larry G., and James N. (1998) The Impact of Ownership Structure on Corporate Debt Policy: a Time-Series Cross-Sectional Analysis, The Financial review, Page: 85-98

Mulyono, Pudjo, Teguh. (1995) Analisa Laporan Keuangan Perbankan, Djabatan Jakarta. Nazir, Moh., (2005) Metode Penelitian, Bogor: Ghalia Indonesia.

Nikomborirak, Deunden dan Tangkitvanich, Somkiat, (1999) Thai Corporate Governance: From Crisis to Recovery, AT10 Researchers Meeting, Januari 2009

Organisation for Economic Co-Operation and Development. (2002) Survey of Corporate Governance Development in OECD Countries. OECD, Paris.

Organisation for Economic Co-Operation and Development. (2004) OECD Principles of Corporate Governance. OECD, Paris.

Pandey, I.M. (2003) Capital Structure and Market Power Interction: Evidence from Malaysia, In Zamri ahmad, Ruhani Ali, Subramaniam Pillay. Proceedings for the fourth annual Malaysian Finance Association Symposium 31 May June 2002.Penang.Malaysia.

Pranata, Yudha. (2007) Pengaruh Penerapan Corporate Governance terhadap Kinerja Keuangan Perusahaan, Skripsi yang dipublikasikan

Rajgopal, Shivaram, dan Mohan Venkatachalam dan James Jiambalvo. (1999) "Is Institutional Ownership Associated with Earnings Management and The Extent to which Stock Price Reflect Future Earnings". Working Paper.

Rawi. (2008) Pengaruh Kepemilikan Manajemen, Institusim dan Leverage Terhadap Corporate Social Responsibility pada Perusahaan Manufaktur yang Listing di Bursa Efek Indonesia, Tesis yang diajukan sebagai salah satu syarat Memperoleh derajat S2 Magister Akuntansi

Retno, Etty, (2005) Good Corporate Governance: Konsep, Prinsip, dan Praktik, Lembaga Komisaris dan Direktur Indonesia

Riyanto, Bambang, (2001) Dasar-dasar Pembelanjaan Perusahaan. Yogyakarta: BPFE

Sabrinna, Ira. A, (2010) Pengaruh Corporate Governance dan Struktur Kepemilikan Terhadap Kinerja Perusahaan, Skripsi Yang Diterbitkan. Semarang: Universitas Diponegoro 
Setyawan, Ari. (2006) Hubungan Antara Corporate Governance dengan Kinerja perusahaan. Skripsi Tidak Diterbitkan. Yogyakarta: Program Studi Akuntansi Universitas Islam Indonesia.

Shleifer, A., \& R. W. Vishny (1997) "Large Shareholders and Corporate Control”, Journal Political Economy", 17:461-488

Sucipto, (2003) Penilaian Kinerja Keuangan, USU digital library

Sudarma, Made. (2004) Pengaruh Struktur Kepemilikan Saham, Faktor Intern dan Faktor Eksterrn Terhadap Struktur Modal dan Nilai Perusahaan. Distertasi, Program Pascasarjana Universitas Brawijaya Malang (Tidak Dipublikasikan)

Sugiyono. (2002) Metode Penelitian Bisnis, Bandung: CV. Alfabeta.

Sujoko dan Ugy Soebiantoro. (2007) "Pengaruh Struktur Kepemilikan, Leverage, Faktor Intern, dan Faktor Ekstern Terhadap Nilai Perusahaan (Studi Empirik pada Perusahaan Manufaktur dan Non Manufaktur di Bursa Efek Jakarta)". Jurnal Manajemen dan Kewirausahaan. Vol. 9. No. 1. Maret, pp. 41-48

Suranta, Eddy dan Mas'ud Machfoedz. (2003) “Analisis Struktur Kepemilikan, Nilai Perusahaan, Investasi dan Ukuran Dewan Direksi”, Simposium Nasional Akuntansi VI. Surabaya

Tarjo. (2008) Pengaruh Konsentrasi Kepemilikan Institusional dan Leverage Terhadap Manajemen Laba, Nilai Pemegang saham serta Cost of Equity Capital. Simposium Nasional Akuntansi XI. Pontianak

Ullman, A. (1985) Data in search of a theory: A critical examination of the relationships among social performance, social disclosure, and economic performance of US firms, Academy of Management eview, Vol. 10, Iss. 3, pp. 540-557.

Van Horne, James C and John M. Wachowicz, Jr, (1998) Prinsip-prinsip Manajemen Keuangan, Edisi Sembilan, Edisi Indonesia, Salemba Empat, Jakarta.

Wahidawati. (2001) Pengaruh kepemilikan Manajerial dan Kepemilikan Institusional pada Kebijakan Hutang Perusahaan: Sebuah perspektif Agency Theory. Simposium Nasional Akuntansi IV.

Wahyudi, Untung dan Hartini P. Pawestri. (2006) Implikasi Struktur Kepemilikan Terhadap Nilai Perusahaan: Dengan Keputusan Keuangan Sebagai Variabel Intervening. Simposium Nasional Akuntansi (SNA) IX Padang.

Wening, Kartikawati. (2009) Pengaruh Kepemilikan Institusional Terhadap Kinerja Keuangan Perusahaan. http://hana.wordpres/2009/05/17/pengaruh kepemilikaninstitusionalterhadap-kinerja-keuangan-perusahaan/,

Zhuang. (2000) Corporate Governance and Finance in East Asia: A Study of Indonesian, Republik of Korea, Malaysia, Philippines, and Thailand. Asia Development Bank. 